\title{
An Investigation into Islamic Corporate Real Estate Sustainable Management (I-Cresm) Practices
}

Nurul Sahida Fauzi, Ashrof Zainuddin, Nor Nazihah Chuweni, Noraini Johari, Abdul Hadi Nawawi

To Link this Article: http://dx.doi.org/10.6007/IJARBSS/v11-i1/9019

DOI:10.6007/IJARBSS/v11-i1/9019

Received: 09 December 2020, Revised: 11 January 2021, Accepted: 19 January 2021

Published Online: 29 January 2021

In-Text Citation: (Fauzi et al., 2021)

To Cite this Article: Fauzi, N. S., Zainuddin, A., Chuweni, N. N., Johari, N., \& Nawawi, A. H. (2021). An Investigation into Islamic Corporate Real Estate Sustainable Management (I-Cresm) Practices. International Journal of Academic Research in Business and Social Sciences, 11(1), 978-985.

\section{Copyright: @ 2021 The Author(s)}

Published by Human Resource Management Academic Research Society (www.hrmars.com)

This article is published under the Creative Commons Attribution (CC BY 4.0) license. Anyone may reproduce, distribute, translate and create derivative works of this article (for both commercial and non-commercial purposes), subject to full attribution to the original publication and authors. The full terms of this license may be seen at: http://creativecommons.org/licences/by/4.0/legalcode

Vol. 11, No. 1, 2021, Pg. 978 - 985

Full Terms \& Conditions of access and use can be found at http://hrmars.com/index.php/pages/detail/publication-ethics 


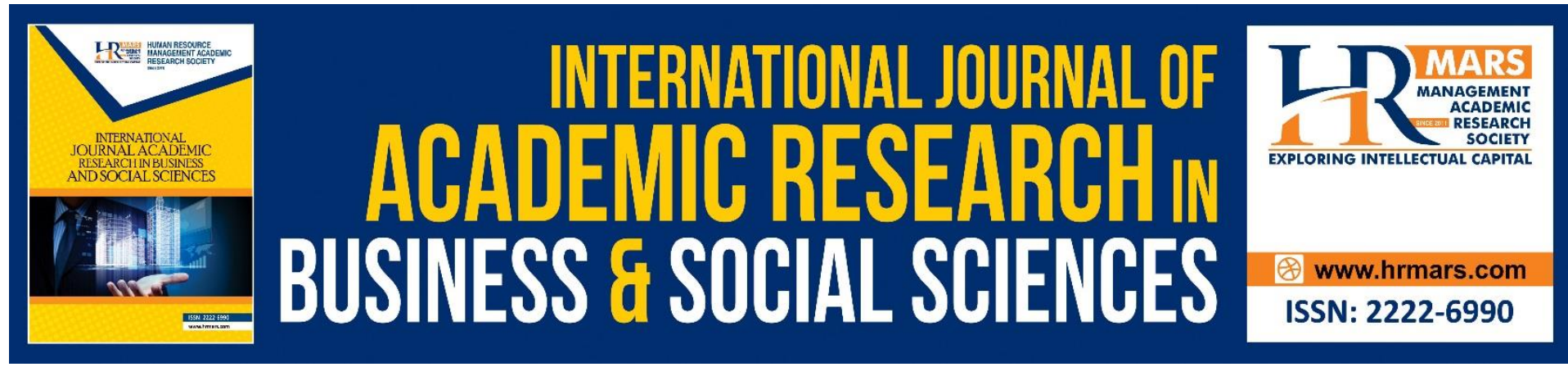

\title{
An Investigation into Islamic Corporate Real Estate Sustainable Management (I-Cresm) Practices
}

\author{
Nurul Sahida Fauzi ${ }^{1}$, Ashrof Zainuddin ${ }^{1}$, Nor Nazihah \\ Chuweni ${ }^{1}$, Noraini Johari ${ }^{1}$, Abdul Hadi Nawawi ${ }^{2}$ \\ ${ }^{1}$ Department of Estate Management, Faculty of Architecture, Planning and Surveying, \\ Universiti Teknologi MARA, Perak Branch, Seri Iskandar Campus, Seri Iskandar, 32610 Perak, \\ Malaysia, ${ }^{2}$ Department of Estate Management, Faculty of Architecture, Planning and \\ Surveying, Universiti Teknologi MARA, Shah Alam, 40450 Shah Alam, Malaysia
}

\begin{abstract}
Shariah-compliant products are now widely accepted especially in the Islamic countries. Similarly, shariah-compliant services are increasingly gaining global market recognition albeit still inattentive in the management practice.Management practices, including real estate management practice, are more concernedwith the sustainable movement. Sustainability is, in fact part of the Islamic principlesin managing this earth. Therefore, a sustainable practice in management should embed Islamic principles and values in order to make it shariah compliant. Accordingly, this paper proposes to investigate the Islamic practice in corporate real estate sustainable management in order to identify the Islamic practices incorporated in sustainable management. The existing Islamic practices are identified through a comprehensive review of current academic literature. An exploratory study was conducted through face-to-face semi structured interviews with ten corporate real estate managers directly involved in managing green office buildings. Results indicate nine (9) principles of sustainable practice for CREM that include sustainable utilization of water, organizational management and good governance, human satisfaction, environmental protection, internal green management, waste management, energy management, innovation, and workspace management. This paper suggests further investigation to be
\end{abstract}

Keywords: Corporate Real Estate Sustainable Management, Islamic Principle

\section{Introduction}

The demand for Islamic products and services keep increasing in the global market. It is proof of the world community's rising acceptance of Islamic principles in business trades. Islam teaches Muslims to be more ethical in their endeavors. Muslims derive their work ethics from guidelines set out in the Qur'an (book revealed by Allah S.W.T) and the sunnah (the recorded sayings and behaviors of Prophet Muhammad pbuh). The goals preached by Islam are not primarily materialistic but more focused on a balanced life between material and spiritual wellbeing in accordance with Islamic principles. Unfortunately, corporations perceive Islamic 
management practices as unattractive and not trendy. Sustainability is the current trend adopted in management, where more businesses embed sustainable concerns in their management practices; real estate management practice included. In fact, sustainability is one of the tenets of Islamic management principles preached to Muslims since the beginning of the faith. Sustainability teachings are scattered in a plethora of verses in the Qur'an and Sunnah. Theseteachings stress on the roles and responsibilities of man as Khalifatullah (the vicegerent of Allah) onearth to care for and preserve the environment; and prohibit man to do mischief on earth.

\section{Islamic Corporate Real Estate Sustainable Management Practices (I-cresm)}

i-CRESMis a combination of corporate real estate sustainable management practices that embed triple bottom line sustainable principles of environmental, social and economic principles as mentioned by Ziemba, Ramian, \& Kania(2015) and Fauzi, Zainuddin, Mohd Ali, \& Nawawi (2016).Fauzi, Zainuddin, Johari, \& Nawawi (2019)have identified Islamic management principles guidelines from Al-Qur'an andasSunnah. The practice of i-CRESM is foundedon balanceand continuous enhancement ofman's material and non-material prosperities both here on earth and in the hereafter(Julia, Kassim, \& Engku Ali, 2018). It involvesrenewable resources and ecological capabilities to support human life(Ahmad Sarkawi et al., 2016). It is crucial that i-CRESM parallels the corporate objectives(Fauzi et al., 2016). i-CRESM differs from conventional practice in that it adopts Islamic principles and is implemented in accordance with the Shariah principles and strained on moral values (Darus et al., 2013). Referring to Mhd Sarif, Ismail, \& Azan(2017), there are three (3) dimensions of shariah including the straightness of a path (istiqamat al-tariq); the balance and justice (al' $a d l$ ) and directive destination (al-i'timad). This view is supported by Julia et al., (2018) who wrote that "shariah is life" which infers that life and shariah are complementary to each other.

lyad Abumoghli (2016) has found several elements of Islamic practice for sustainable development that are suitable for adoption in i-CRESM practice. Several researcherssupport his views in various elements such as sustainable utilization of water including its efficient use and its conservation by Miswan@ Abdul Hakin, Abdul Hamid, \& Adibah (2009); organizational managementby Mohamad \& Hussein(2018); and knowledge and educationby Julia et al. (2018). Julia et al.(2018) together with Mohamad \& Hussein (2018) also provided fruitful findings on environmental protection, waste generation(Julia et al., 2018), cultural and ethnic values, and responsibility towards the disabled and the poor(Julia et al., 2018).Not only that, Julia et al. (2018) also discovered several other elements that are more focusedon human wellbeing notably employees, customers, and community. The latest edition on i-CRESM practice was found in Fauzi et al. (2019) that sharedeight (8) elements including sustainable utilization of water, organizational management and good governance, human satisfaction (employees, occupants, customers), environmental protection, waste generation, energy management, innovation, and workspace management.

\section{Research Method}

The fundamental study imposed an exploratory research method approach where the collection of data was through face-to-face interviews with ten (10) managers of green CRE. The green CREs selected are limited to the green office buildings that have obtained green building index (GBI) certification only. This is becausethe GBI certification is a Malaysian green certification exercise that takes into consideration the Malaysian climate. Details of selected 
participants and their years of experience are listed in Table 1.The semi-structured interview questionswere designed in accordance with the Islamic principles found from previous research on i-CRESM. The researcher took liberty to add several other relevant questions during the interview sessions. New findings from interview sessions were recorded, highlighted and deeply explored during the sessions.Data gathered is then transcribed and analyzed through thematic analysis using atlas.ti and later presented in table form.

\begin{tabular}{|lcl|}
\hline $\begin{array}{l}\text { Table 1 } \\
\text { Participant's Profile }\end{array}$ & \\
\hline Participants & Experience in Real Estate (years) & Experience in CRESM (years) \\
\hline P1 & 27 & 6 \\
P2 & 32 & 5 \\
P3 & 27 & 3 \\
P4 & 30 & 3 \\
P5 & 30 & 4 \\
P6 & 22 & 3 \\
P7 & 21 & 5 \\
P8 & 15 & 5 \\
P9 & 10 & 5 \\
P10 & 10 & 6 \\
\hline
\end{tabular}

\section{Findings and Conclusion}

This study publishesnine(9) Islamic principles and several itemsof i-CRESM practicesadopted and implemented by the managementas stated in Table 2. It recommends conducting further investigation involving a larger number of participation in order to gather more data and to generalize the results. 
Table 2

Elements involved in i-CRESM Practice

\begin{tabular}{|c|c|c|c|c|c|c|c|c|c|c|}
\hline Participants & \multirow[t]{2}{*}{ P1 } & \multirow[t]{2}{*}{$\mathrm{P} 2$} & \multirow[t]{2}{*}{ P3 } & \multirow[t]{2}{*}{ P4 } & \multirow[t]{2}{*}{ P5 } & \multirow[t]{2}{*}{ P6 } & \multirow[t]{2}{*}{ P7 } & \multirow[t]{2}{*}{ P8 } & \multirow[t]{2}{*}{ P9 } & \multirow[t]{2}{*}{ P10 } \\
\hline Sustainable Practices & & & & & & & & & & \\
\hline $\begin{array}{l}\text { Sustainable utilization of water } \\
\text {-Rain water harvesting } \\
\text {-Recycle grey water } \\
\text {-Automated irrigation } \\
\text {-Water saving fitting } \\
\text {-Green cleaning policy } \\
\text {-Systematic control on water consumption } \\
\text {-Metering and leak detection system }\end{array}$ & $\begin{array}{l}\dot{.} \\
. \\
. \\
.\end{array}$ & $\begin{array}{l}\dot{.} \\
\dot{.}\end{array}$ & $\begin{array}{l}\dot{.} \\
\dot{.} \\
\dot{.} \\
\text {. }\end{array}$ & $\begin{array}{l}\dot{.} \\
\dot{.} \\
\dot{.}\end{array}$ & $\begin{array}{l}\dot{.} \\
\dot{s} \\
\dot{.}\end{array}$ & $\begin{array}{l}\dot{.} \\
\dot{.} \\
\dot{.} \\
.\end{array}$ & . & $\begin{array}{l}\dot{.} \\
\dot{.} \\
\dot{.}\end{array}$ & . & $\begin{array}{l}. \\
. \\
.\end{array}$ \\
\hline $\begin{array}{l}\text { Organizational management and good } \\
\text { governance } \\
\text {-In line with company vision and mission } \\
\text {-Top management concern on sustainability } \\
\text {-Managed by qualified and experienced person } \\
\text {-Managed by adequate team } \\
\text {-Reporting direct to corporate top management } \\
\text {-Good governance } \\
\text {-Practising principles of Islam(shariah } \\
\text { compliance) }\end{array}$ & $\begin{array}{l}\dot{.} \\
. \\
\dot{.} \\
.\end{array}$ & . & . & $\begin{array}{l}\dot{.} \\
\dot{.} \\
\text {. }\end{array}$ & . & . & $\begin{array}{l}\dot{.} \\
\dot{.} \\
\dot{.}\end{array}$ & $\begin{array}{l}. \\
. \\
.\end{array}$ & $\begin{array}{l}\dot{.} \\
\dot{.} \\
\dot{.}\end{array}$ & $\begin{array}{l}\dot{.} \\
\dot{.} \\
\dot{.}\end{array}$ \\
\hline $\begin{array}{l}\text { Human satisfaction } \\
\text { (employees, occupants, customers) } \\
\text {-Knowledge and education } \\
\text {-Provide motivation and training for employees } \\
\text {-Provide pleasant working environment } \\
\text {-Provide functional workplace }\end{array}$ & . & : & i. & . & $\dot{.}$, & $\dot{.}$. & $\begin{array}{l}. \\
. \\
. \\
.\end{array}$ & . & i. & $\begin{array}{l}\dot{\prime} \\
\dot{s}\end{array}$ \\
\hline $\begin{array}{l}\text { Participants } \\
\text { Sustainable Practice }\end{array}$ & P1 & $\mathrm{P} 2$ & P3 & P4 & P5 & P6 & P7 & P8 & P9 & P10 \\
\hline $\begin{array}{l}\text {-Strictly monitored health, safety and security } \\
\text { aspects } \\
\text {-Consideration of occupant comfort } \\
\text {-Consideration of privacy aspects } \\
\text {-Provide green recreational area } \\
\text {-Provide indoor entertainment area } \\
\text {-Corporate Social Responsibility } \\
\text {-Systematic complaints system } \\
\text {-Feedback analysis } \\
\text {-Ample signage in the building } \\
\text {-Comfortable waiting area } \\
\text {-Maintain cultural and ethnic values }\end{array}$ & . & . & $\begin{array}{l}\dot{.} \\
\dot{.} \\
\dot{.} \\
\dot{.} \\
.\end{array}$ & $\begin{array}{l}\dot{.} \\
\dot{.} \\
\text {. }\end{array}$ & . & . & . & & . & $\begin{array}{l}. \\
. \\
. \\
. \\
. \\
. \\
.\end{array}$ \\
\hline $\begin{array}{l}\text { Environmental protection } \\
\text {-Use eco-friendly equipment } \\
\text {-Green cleaning policy } \\
\text {-Supplier assessment on eco product } \\
\text {-Apply environmental assessment system } \\
\text {-Use recycled materials } \\
\text {-Use hazard- free materials }\end{array}$ & $\begin{array}{l}. \\
. \\
.\end{array}$ & . & . & $\begin{array}{l}. \\
. \\
.\end{array}$ & . & . & , & . & . & \\
\hline $\begin{array}{l}\text { Internal Green Management } \\
\text {-Provide natural ecosystem inside and outside of } \\
\text { the building } \\
\text {-Apply scheduled landscape management } \\
\text {-Control humidity in the building }\end{array}$ & ' & ' & ' & . & . & ; & ' & . & . & . \\
\hline
\end{tabular}


-Control air quality in the building

-Control air temperature in the building

-Control daylighting and glare in the building

-Provide internal noise control

-Provide healthy internal and external views

\section{Waste generation}

-provide recycle bins

-recycle bins used wisely

-sell off recycled waste materials

-provide waste management plan

-organic waste is used back

-provide e-waste collection schedule

\section{Energy management}

-Systematic control on energy use -Automated energy management system

-Efficient energy management team

-Effective PPM schedule

-Use natural energy sources

-Sell out generated natural resources

-Minimum use of energy

-Use energy saving appliances

-Use energy saving fittings

-Automated daylighting control

-Apply lightning zone and control

\begin{tabular}{|c|c|c|c|c|c|c|c|c|c|c|}
\hline $\begin{array}{c}\text { Participants } \\
\text { Sustainable Practices }\end{array}$ & P1 & P2 & P3 & P4 & P5 & P6 & P7 & P8 & P9 & P10 \\
\hline \multicolumn{11}{|l|}{ Innovation } \\
\hline -Provide innovation in management system & ' & ' & ' & ' & ' & ' & ' & ' & , & \\
\hline $\begin{array}{l}\text {-Provide innovation in building maintenance } \\
\text { and controlling systems }\end{array}$ & ' & $\cdot$ & - & ' & ' & ' & ' & ' & ' & - \\
\hline $\begin{array}{l}\text {-Provide innovation in delivering information } \\
\text { system }\end{array}$ & ' & ' & - & - & ' & ' & ' & ' & ' & \\
\hline $\begin{array}{l}\text {-Provide innovation in environmental design } \\
\text { initiatives }\end{array}$ & ' & ' & ' & - & ' & ' & ' & - & $\cdot$ & ' \\
\hline $\begin{array}{l}\text {-Artificial intelligence to design the apps and } \\
\text { system for the corporation }\end{array}$ & ' & ' & ' & ' & $\cdot$ & ' & ' & ' & ' & ' \\
\hline $\begin{array}{l}\text {-Adopt the Industrial Revolution } 4.0 \text { in the } \\
\text { innovation }\end{array}$ & ' & ' & - & - & - & - & ' & ' & - & - \\
\hline \multicolumn{11}{|l|}{ Workspace management } \\
\hline -The design encourages optimum use of space & ' & ' & - & - & ' & - & ' & ' & ' & - \\
\hline $\begin{array}{l}\text {-Provide a suitable workspace design and - } \\
\text { layout }\end{array}$ & ' & - & - & - & - & ' & ' & - & ' & \\
\hline -The design encourages human interaction & ' & ' & ' & ' & ' & ' & ' & $\cdot$ & ' & ' \\
\hline $\begin{array}{l}\text {-The workspace design referring to the } \\
\text { standard }\end{array}$ & ' & ' & ' & 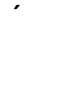 & 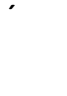 & ' & ' & ' & ' & 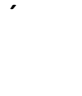 \\
\hline -Equipped with smart and intelligent system & ' & 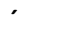 & 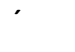 & 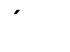 & & & 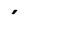 & 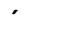 & 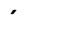 & 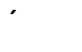 \\
\hline -Accessible working space design & , & ' & & ' & & & , & , & & \\
\hline
\end{tabular}




\section{Corresponding Author}

Nurul Sahida Fauzi

Department of Estate Management, Faculty of Architecture, Planning and Surveying, Universiti Teknologi MARA, Perak Branch, Seri Iskandar Campus, Seri Iskandar, 32610 Perak, Malaysia

ochidsahidafauzi@gmail.com

\section{References}

Sarkawi, A., Abdullah, A., \& Md. Dali, N. (2016). The concept of sustainability from the islamic perspectives. International Journal of Business, Economics and Law, 9(5), 112-116.

Darus, F., Yusoff, H., Abang Naim, D. M., Zain, M., Amran, A., Fauzi, H., \& Purwanto, Y. (2013). Islamic corporate social responsibility ( $\mathrm{i}-\mathrm{CSR}$ ) framework from the perspective of maqasid al- Syariah and maslahah. Social and Environmental Accounting, 7(2), 102-112.

Fauzi, N. S., Zainuddin, A., Johari, N., \& Nawawi, A. H. (2019). Review on Islamic corporate real estate sustainable management (i-CRESM) practice. In International Conference on Islamic Research in Management, Education, Social Science and Technology (ICIRMEST 2019) (pp. 1-6).

Fauzi, N. S., Zainuddin, A., Mohd Ali, S. N., \& Nawawi, A. H. (2016). A preliminary framework for corporate real estate sustainable management. International Building Conference Control, 00062. http://doi.org/10.1051/matecconf/20166600062

Abumoghli, I. (2016). Islamic Principles on Sustainable Development.

Julia, T., Kassim, S., \& Engku Ali, E. R. A. (2018). Are the green projects in line with the maqasid shariah ? An assessment of green firms in Bangladesh. In Global Conference on Islamic Economics and Finance 2018 24th \& 25th October 2018 / Sasana Kijang, Bank Negara Malaysia, Kuala Lumpur (pp. 317-335).

Sarif, M. S., Ismail, Y., \& Azan, Z. (2017). Effects of maqasid al-shariah for ethical decision making. Journal of Islamic Management Studies, 1(1), 01-14.

Mohamad, M., \& Hussein, S. M. (2018). Stratified property management : Islamic aspect. International Journal of Asian Social Science, 8(11), 1005-1016. http://doi.org/10.18488/journal.1.2018.811.1005.1016

Ziemba, E., Ramian, T., \& Kania, K. (2015). The Concept of a Sustainable Approach to Corporate Real Estate Management. Real Estate Management and Valuation, 23(4), 8594. 